\title{
Muscle graft as a substitute for peripheral nerve graft in rats $^{1}$
}

\author{
Enxerto de músculo como substituto de nervo periférico em ratos
}

\author{
Aristides Palhares ${ }^{\mathrm{I}}$, Fausto Viterbo', Ricardo Galesso Cardoso ${ }^{\mathrm{II}}$ \\ ${ }^{\text {I }} \mathrm{PhD}$, Assistant Professor, Department of Surgery and Orthopedic, Botucatu Faculty of Medicine, UNESP, Brazil.

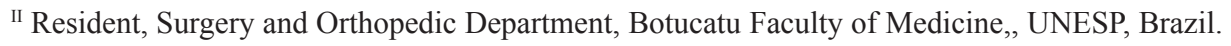

\begin{abstract}
Purpose: To evaluate the applicability of the use of autogenous muscle treated in various ways, as a substitute of the nerve grafts. Methods: Rats were divided into seven groups that received, as a treatment for a standard nerve injury, the following types of grafts: fresh muscle, muscle fixed with $10 \%$ formaldehyde, muscle frozen in a freezer, muscle frozen in refrigerator, nerveless muscle, peripheral nerve and a group was without any treatment. It assessed the histological appearance of the nerve fibers in the segment repaired. Results: The evaluation of the segment nervous repaired showed nerve fibers through the graft in almost all groups, but the methodology employed has not adequately characterized the differences between the groups. Conclusion: This study showed the migration of nerves fibers through all grafts used.
\end{abstract}

Key words: Animal Experimentation. Nerve, Regeneration. Muscle, Skeletal. Transplantation, Autologous. Rats.

\section{RESUMO}

Objetivo: Avaliar a aplicabilidade do uso de músculo autógeno, tratado de diversas maneiras, em substituição aos enxertos de nervo. Métodos: Os ratos foram separados em sete grupos que receberam, como tratamento a uma lesão nervosa padronizada, os seguintes tipos de enxertos: músculo fresco, músculo fixado com formol 10\%, músculo congelado em freezer, músculo congelado em refrigerador, músculo denervado, nervo periférico e um grupo ficou sem qualquer tratamento. Foi avaliado o aspecto histológico das fibras nervosas no segmento reparado. Resultados: A avaliação do segmento nervoso reparado mostrou que existiam axônios em quase todos os grupos, mas a metodologia empregada não possibilitou caracterizar adequadamente as diferenças entre os grupos. Conclusão: Este estudo mostrou a migração de axônios por meio de todos os enxertos utilizados.

Descritores: Experimentação Animal. Regeneração Nervosa. Músculo Esquelético. Transplante Autólogo. Ratos.

${ }^{1}$ Research performed at Experimental Surgery Laboratory, Surgery and Orthopedic Department, ,Botucatu Faculty of Medicine, UNESP, Brazil.

\section{Introduction}

Peripheral nerve surgery has undergone many advancements within the past hundred years; microsurgery was introduced, several suturing techniques were created and autogenous nerve grafts became popular.

Despite all these advancements, it has not been possible to completely resolve the situations in which the loss of a nerve segment prevents repair of the stumps by direct frontal approach.

The first repair proposal, in this case, would suggest bone shortening to enable suturing of the nerve, but soon several other less aggressive approaches were proposed in order to repair these injuries ${ }^{2}$.

Nowadays, the autologous nerve graft is still the most frequently used method ${ }^{1}$ except for some cases in which there is not sufficient nerve for grafting or where there is a great mismatch between the calipers of the nerve to be repaired and the nerve utilized for the graft.

Subsequent studies showed that within tissue culture, the axons grow particularly well when the substrates contain the basal membrane components, particularly laminin and fibronectin. It has become theoretically possible to create grafts that reconstruct nerves from tubes parallel of basal membrane with exactly the same structure as skeletal muscles $s^{3,9,10,11}$.

Among the studies in this area we can cite are from: Fawcet and Keynes ${ }^{3}$, Glasby et $a l .{ }^{7}$ and ${ }^{8}$, Norris et $a l .{ }^{12}$, Gattuso et al..$^{5,6}$, Feneley et al.4 and Rath and Green ${ }^{13,14}$.

We have thus decided to evaluate the use of skeletal muscle basal membrane as a substitute for autologous nerve grafts.

Our main concern was the complexity of the treatment required to obtain the basal membrane from autologous muscle before it could be utilized as a substitute for autologous nerve in nerve grafting and also the need for this procedure since the literature indicates that even with such procedures the cellular membrane elimination was not thorough and that in rabbits, about $50 \%$ of the cellular membrane was removed ${ }^{3}$.

Therefore, we decided to evaluate some simple and less expensive alternative methods.

The present study aimed to study grafts utilizing autogenous muscle, treated in different manners, instead of employing a nerve segment. 


\section{Methods}

All the procedures performed on rats abided by the Ethical Principles for Animal Experimentation recommended by COBEA (Brazilian Council for Animal Experimentation).

After a $30-\mathrm{mg} / \mathrm{kg}$ dose of pentothal sodium via intra peritoneal anesthesia, the right posterior face of the rat's thigh was shaved.

An incision of approximately seven centimeters was made at the posterior edge of the rat's right thigh. The femoral biceps and gluteus maximus muscles were lifted, exposing the space through which the sciatic nerve and its branches pass. They were then identified and separated. The fibular nerve was isolated and a paper gauge was placed underneath it. From this moment on, the procedures started to diversify according to the group to which the rat belonged, as follows:

Group 1 -Fresh muscle: In this group of 20 rats, after identification and fibular nerve isolation, a segment of one centimeter was removed. This injury was repaired by using a fresh muscle graft removed from the ipsolateral femoral biceps muscle, compatible with the size and shape of the receptor nerve, and it was fixed with two 9.0 surgical nylon stitches on each of the stumps.

Group 2 - Muscle fixed by formaldehyde: Also with 20 rats; at the moment of the first surgery, a segment of the femoral biceps muscle was removed and fixed in a $10 \%$ formaldehyde solution. This muscular tissue was approximately 50\% larger than the injury to be treated. After 24 hours the rat was submitted to a second surgery and an injury of one centimeter was produced on the fibular nerve, and it was immediately repaired using part of the muscle that had been fixed by formal the day before.

Before its implantation, the fixed muscular tissue was washed with $100 \mathrm{ml}$ of saline, in which it was left immersed for approximately 60 minutes. For the nerve repair we used the same suture type as in the prior group, removing the excessive tissue in order to obtain a good match between the nerve size and the implanted muscle.

Group 3 -Freezer-frozen muscle: In this group, 20 rats were operated on using the same technique described previously, except that the muscle was fixed by freezing it in a domestic freezer for 24 hours at a temperature of $-10^{\circ} \mathrm{C}$. The muscular tissue was reheated by immersion in the saline at room temperature for one hour until its implantation.

Group 4 -Refrigerator-frozen muscle: In this group 20 rats were submitted to surgery. The only difference in comparison to the anterior group was that muscle utilized to repair the nerve injury was frozen in an ordinary refrigerator at $-3^{\circ} \mathrm{C}$.

Group 5-Nerveless muscle: For the 20 rats in this group an initial left cranial tibial muscle nerve removal was performed by sectioning the left fibular nerve and burying its stumps under non-contiguous adjoining muscles. After 42 to 57 days, a one-centimeter fragment from the left cranial tibial muscle was removed in order to repair the injury caused by the removal of the one-centimeter segment from the right fibular nerve.

Group 6-Autologous graft: Done with ten rats, this group differed from the anterior by virtue of the fact that we sectioned the fibular nerve at two different spots, one centimeter apart. This segment, originated by the sectioning, was used to repair the produced injury, as an autologous graft.
Group 7-No treatment: Also done with ten rats; although we sectioned the fibular nerve at two different spots, one centimeter apart, to create the same standard injury, this group differed from Group 6 in that no treatment was performed. The nerve stumps were fixed to the adjoining muscle tissue with a single 9.0 surgical nylon stitch.

For all groups the rats were observed for an average time of 275 days, with 229 and 328 days being the shortest and longest periods, respectively. This period included the time between the repair procedure, fibular nerve lesion and the date of rats' sacrifice and removal of the tissues for histological exams.

The rats were sacrificed by a lethal intra-peritoneal anesthetic dose immediately after removal of the tissues to be studied.

In order to perform histological studies, some fragments from the sutured fibular nerve were collected. These fragments were then transversely sliced and EH-dyed and were used to evaluate the nerve's structural fibers.

The slides were randomized and analyzed in an Olympus $\mathrm{CH} 40$ microscope at objectives of 20,40, and $100 \mathrm{X}$; the original magnification was between 200 and 1,000 X.

In order to compare the achieved results, we established a standard for assigning organization grades from 1 through 4 for the nerve cuts such that:

Score \# 1: This value was assigned to the cuts that did not show any organization. In these, the axons were dispersed and with little formation of micro-fascicles (Figure 1).

Score \# 2: We bestowed this score on cuts with a slightly higher degree of organization. Furthermore, the fascicles were grouped into micro- or small fascicles (Figure 2).

Score \# 3: The structural organization in cuts with this score had more definition, with 1 to 3 larger fascicles; the number of axons or micro-fascicles is small (Figure 3).

Score \# 4: The histological cuts receiving this score presented a structure similar to the typical nerve. A large fascicle, coated by perineurium and surrounded by axons (Figure 4).

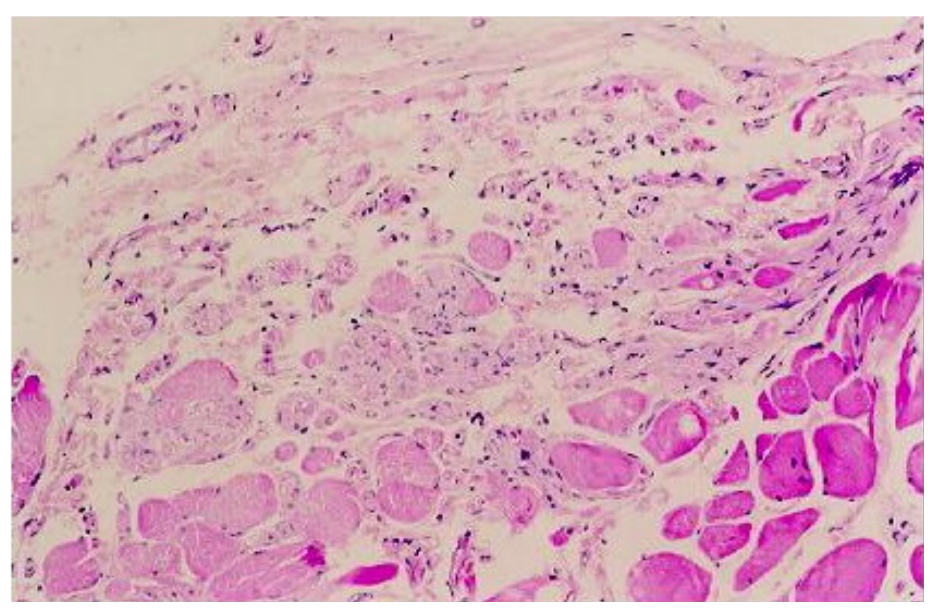

FIGURE 1 - Note that the nerve fibers are distributed at random, surrounded by connective tissue and muscle fibers 


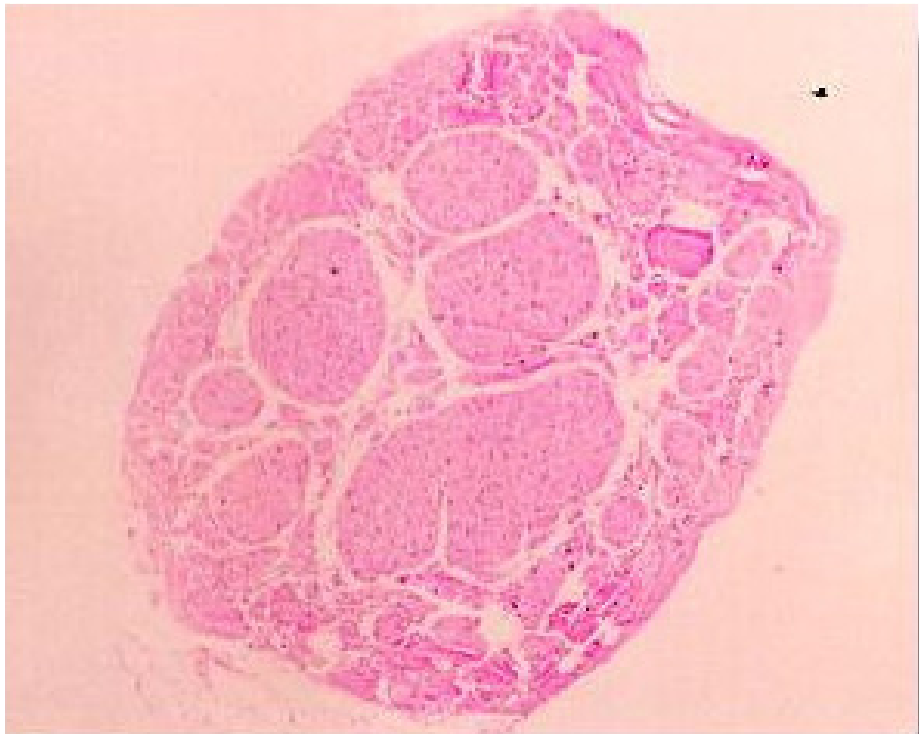

FIGURE 2 - In that slide can highlight many small fascicles and areas with micro- fascicles

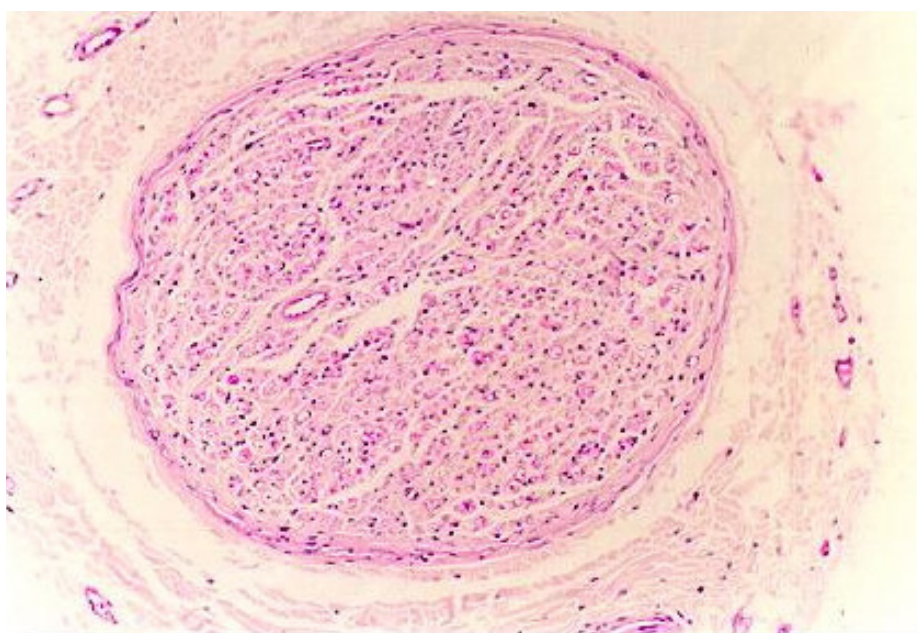

FIGURE 4 - Structure similar to a normal nerve. Note that there is a big fascicles and there are no groups of around axônio

The rats were under observation for an average time of 275 days, with 229 and 328 days being the shortest and longest periods, respectively.

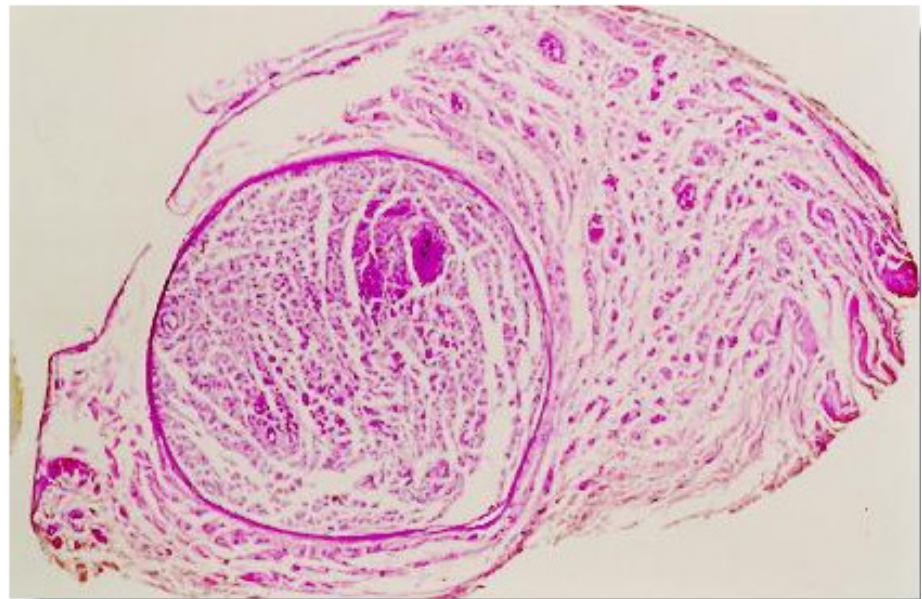

FIGURE 3 - This slide drew attention the presence of a large fascicles, but there are still minor fascicles and micro-issues fascicles

\section{Structural analysis - Employed techniques}

The objective of the performed analysis was to determine the differences in the organizational structure among the different study groups.

Before initiating the data analysis we tested the type of distribution in our sample based on the principle that the parametric statistical tests evaluate the intra-group differences presuming a normal distribution for each variant tested. It became clear that for at least one group, the "normality" hypothesis should be rejected. Based on this result and the variability of sample size (the number varied between 6 and 18 since there had been rat mortality and technical mishaps at the laboratory that hindered the analysis of all the slides), we chose to analyze differences by the non-parametric Kruskal-Wallis test.

\section{Results}

\section{Statistical analysis}

The statistical analysis was based upon the group data displayed in the table below (Tables 1 to 4 ):

TABLE 1 - Scores average distribution by group

\begin{tabular}{ccccccc}
\hline GROUP & $\#$ & Average & Standard D. & Minimum & Maximum & CI \\
\hline 1 & 15 & 2.00 & 0.676 & 1 & 3 & $1.826 ; 2.574$ \\
2 & 15 & 2.00 & 0.00 & 2 & 2 & $2.00 ; 2.00$ \\
3 & 18 & 2.00 & 0.583 & 1 & 3 & $1.827 ; 2.401$ \\
4 & 18 & 2.00 & 0.323 & 1 & 2 & $1.728 ; 2.050$ \\
5 & 18 & 1.00 & 0.600 & 1 & 3 & $1.087 ; 1.691$ \\
6 & 8 & 3.00 & 0.707 & 2 & 4 & $2.159 ; 3.341$ \\
7 & 6 & 1.50 & 0.548 & 1 & 2 & $0.925 ; 2.075$ \\
\hline
\end{tabular}

$\mathrm{CI}=$ Confidence Interval 
TABLE 2 - Kruskal-Wallis analysis of the studied variant

\begin{tabular}{|c|c|c|c|c|c|}
\hline $\begin{array}{l}\text { G1/G2 M Seg } \\
\text { p-value- } \\
\text { KW }=>0.05\end{array}$ & & & & & \\
\hline $\begin{array}{l}\text { G1/G3 M Seg } \\
\text { p-value-KW = } \\
>0.05\end{array}$ & $\begin{array}{l}\text { G2/G3 M Seg } \\
\text { p-value-KW }= \\
>0.05\end{array}$ & & & & \\
\hline $\begin{array}{l}\text { G1/G4 M Seg } \\
\text { p-value-KW = } \\
>0.05\end{array}$ & $\begin{array}{l}\text { G2/G4 M Seg } \\
\text { p-value-KW }= \\
>0.05\end{array}$ & $\begin{array}{l}\text { G3/G4 M Seg } \\
\text { p-value-KW = } \\
>0.05\end{array}$ & & & \\
\hline $\begin{array}{l}\text { G1/G5 M Seg } \\
\text { p-value-KW = } \\
>0.01\end{array}$ & $\begin{array}{l}\text { G2/G5 M Seg } \\
\text { p-value-KW }= \\
>0.05\end{array}$ & $\begin{array}{l}\text { G3/G5 M Seg } \\
\text { p-value-KW = } \\
>0.01\end{array}$ & $\begin{array}{l}\text { G4/G5 M Seg } \\
\text { p-value-KW = } \\
>0.05\end{array}$ & & \\
\hline $\begin{array}{l}\text { G1/G6 M Seg } \\
\text { p-value-KW = } \\
>0.05\end{array}$ & $\begin{array}{l}\text { G2/G6 M Seg } \\
\text { p-value-KW = } \\
>0.05\end{array}$ & $\begin{array}{l}\text { G3/G6 M Seg } \\
\text { p-value-KW = } \\
>0.05\end{array}$ & $\begin{array}{l}\text { G4/G6 M Seg } \\
\text { p-value-KW = } \\
>0.05\end{array}$ & $\begin{array}{l}\text { G5/G6 M Seg } \\
\text { p-value-KW }= \\
>0.01\end{array}$ & \\
\hline $\begin{array}{l}\text { G1/G7 M Seg } \\
\text { p-value-KW = } \\
>0.05\end{array}$ & $\begin{array}{l}\text { G2/G7 M Seg } \\
\text { p-value-KW }= \\
>0.05\end{array}$ & $\begin{array}{l}\text { G3/G7 M Seg } \\
\text { p-value-KW = } \\
>0.05\end{array}$ & $\begin{array}{l}\text { G4/G7 M Seg } \\
\text { p-value-KW = } \\
>0.05\end{array}$ & $\begin{array}{l}\text { G5/G7 M Seg } \\
\text { p-value-KW }= \\
>0.05\end{array}$ & $\begin{array}{l}\text { G6/G7 M Seg } \\
\text { p-value-KW = } \\
>0.05\end{array}$ \\
\hline
\end{tabular}

TABLE 3 - KW test produced graduated sequence for the studied

\begin{tabular}{lc|c|ccccc}
\hline Variant & Groups & \multicolumn{1}{l}{} & & & & \\
\hline M Seg & G6 & G1 & G3 & G2 & G4 & G7 & G5 \\
\hline
\end{tabular}

M Seg = Medial Segment. Location of sample removal.

TABLE 4 - Relation between the groups according to KW test

\begin{tabular}{cc}
\hline Group & $\mathrm{p}-$ value $-\mathrm{KW}$ \\
\hline $\mathrm{G} 6 \neq \mathrm{G} 5$ & $<0.001$ \\
$\mathrm{G} 6 \neq \mathrm{G} 7$ & $<0.05$ \\
$\mathrm{G} 1 \neq \mathrm{G} 5$ & $<0.01$ \\
$\mathrm{G} 3 \neq \mathrm{G} 5$ & $<0.01$ \\
$\mathrm{G} 6=\mathrm{G} 1=\mathrm{G} 3=\mathrm{G} 2=\mathrm{G} 4$ & $>0.05$ \\
\hline
\end{tabular}

$\mathrm{KW}=$ Kruskal-Wallis

\section{Discussion}

The rat was chosen as the experimentation animal for its endurance, ease of treatment and handling and for its frequent use in prior nerve regeneration studies $7,9,10,11$.

Similarly, the sciatic nerve was chosen due to its ease of anatomical positioning and access, as well as the suitability of its length in application of the techniques we aimed to study.

The range of rat observation times, from 229 days up to 328 days, was due to the project's design, which determined that for Group 5, the treatment would be done with autologous nerve previously removed. Thus, in this group the rats were operated on, initially, to remove the nerve from the left tibial cranial muscle and, after a period that varied from 42 days to 58 days, they received nerveless muscle grafts.

In analyzing the performance of the different nerve repair methods utilized, we noted that for Group 6, in which nerve graft was performed, our "Gold Standard" technique had the best performance.

Given that we could demonstrate significant difference 
only between this group and the groups 5, that utilized nerveless muscle, and 7, in which we did not perform any treatment, the propensity shown by the statistical study confirms our expectation of achieving better results in the group submitted to the "Gold Standard" technique.

Although nerve suture is the technique with the best clinical results, the fact that nerve grafts produce regeneration is widely known ${ }^{5,15}$.

Another important aspect was Group 5's performance, in which we utilized nerveless muscle to repair the nerve injury. In this group, we initially expected that the muscle degeneration due to nerve removal would facilitate axon migration through the tubules of the basal membrane from the muscle fibers, producing a nerve of good structural organization. This did not happen. Possibly, the degenerative processes to which the grafted muscle was submitted contributed to the disorganization of the basal membrane tubules or to the volume reduction, thus decreasing the organization of the regenerated nerve.

The methodology utilized for the semi-quantitative study of the structure of the EH-dyed nerve fibers in the nerve segment, repaired with muscle, was unable to demonstrate any conclusive differences between the studied groups.

This task shows new possibilities for the study of peripheral nerve substitutes, and, although our study does not speculate about the efficiency of the utilized methods, we understand that this field deserves further investigation in the future.

\section{Conclusion}

There has been nerve fiber growth throughout the muscle segment among all the studied groups.

\section{References}

1. Bentley FH, Hill M. Possibilities of nerve grafting. Br J Surg. 1940;14:352-3.
2. Dandy WE, A method of restoring nerves requiring resection. J Am Med Assoc. 1943;122:35-6.

3. Fawcett JW, Keynes RJ. Muscle basal lamina: a new graft material for peripheral nerve repair. J Neurosurg. .1986;65:354-63.

4. Feneley MR, Fawcett JW, Keynes RJ. The role of Schwann cells in the regeneration of peripheral nerve axons through muscle basal lamina grafts. Exp Neurol, 991;114:275-85.

5. Gattuso JM, Glasby MA, Gschmeissner SE. Norris RW. A comparison of immediate and delayed repair of peripheral nerves using freeze-thawed autologous skeletal muscle grafts in the rat. Br J Surg. 1989;42:306-13.

6. Gattuso JM, Glasby MA, Gschmeissner SE, Norris R. A comparison of immediate and delayed repair of peripheral nerves using freeze-thawed autologous skeletal muscle grafts in the rat. Br J Surg. 1989;42:306-13.

7. Glasby MA, Gschmeissner S, Hitchcock RJ. Huang CL. Regeneration of the sciatic nerve in rats. The effect of muscle basement membrane. $\mathrm{J}$ Bone Joint Surg 1986;68:829-33.

8. Glasby MA, Gilmour JA, Gschmeissner SE, Hems TE, Myles LM. The repair of large peripheral nerves using skeletal muscle auto grafts: a comparison with cable grafts in the sheep femoral nerve. Br J Plast Surg. 1990;43:169-78.

9. Gu LQ, Zhu JK. Repair of different sized nerve defects using degenerated muscle grafts with vascular implantation: an experimental study in the rat. J Reconstr Microsurg. 1992;8:47-52.

10. Hall SM, Enver K. Axonal regeneration through heat pretreated muscle auto grafts. An immunohistochemical and electronic microscopic study. J Hand Surg. 1994;19:444-51.

11. Król E, Zimnoch L, Skowrohski J. Regeneration of peripheral nerves by muscle auto grafts in rats. I. Morphological and morph metrical evaluation. Neuro Neurochir Pol. 1993;27:547-53.

12. Norris RW, Glasby MA, Gattuso JM, Bowden RE. Peripheral nerve repair in humans using muscle auto grafts. A new technique. J Bone Joint Surg. 1988;70:530-3.

13. Rath S, Green CJ. Selectivity of distal reinnervation of regenerating mixed and sensory nerve fibers across muscle grafts in rats. Br J Plast Surg. 1991;44:215-8.

14. Rath S, Green CJ. Lack of topographical specificity in sensory nerve regeneration through muscle grafts in rats. J Hand Surg Br. 1991;16:524-30. 15. Wong AYC, Scott JJA. Functional recovery following direct or graft repair of nerve gaps in the rat. Exp Neurol. 1991;114:364-6.

\section{Correspondence:}

Aristides Palhares

Alameda Antonio Sartor, 430

18607-340 Botucatu - SP Brazil

Phone: (55 14)3815-5312 / 3811-6230

Fax: (55 14)3815-7615

palhares@fmb.unesp.br

Conflict of interest: none Financial source: none

Received: December 18, 2008

Review: February 19, 2009

Accepted: March 20, 2009

\section{How to cite this article}

Palhares A, Viterbo F, Cardoso RG. Muscle graft as a substitute for peripheral nerve graft in rats. Acta Cir Bras. [serial on the Internet] 2009 May-Jun;24(3). Available from URL: http://www.scielo.br/acb 